\title{
Nitrogen and Carbon Concentrations in the Stomach Content of Bank Voles (Myodes glareolus). Does Food Quality Determine Abundance?
}

\author{
R. Thomas Palo ${ }^{*}, 1$ and Gert E. Olsson ${ }^{2,3}$ \\ ${ }^{I}$ Department of Natural Sciences, Engineering and Mathematics, Mid-Sweden University, SE-851 70 Sundsvall, Sweden \\ ${ }^{2}$ Department of Virology, Swedish Institute for Infectious Disease Control, SE-171 82 Solna, Sweden \\ ${ }^{3}$ Wildlife, Fish, and Environmental studies, Swedish University of Agricultural Sciences, SE-901 83 Umeå, Sweden
}

\begin{abstract}
We found that concentrations of nitrogen $(\mathrm{N})$ in the stomach of voles varied between forest sites. Concentrations of nitrogen as well as the ratio of nitrogen to carbon $(C)$ in stomach content were not different between the sexes or with season. Body mass varied between sites and between seasons but were unrelated to $\mathrm{N}$ concentration in spite that the body mass of voles in the spring season were on average $4.8 \mathrm{~g}$ heavier than in the autumn A positive relationship was found between $\mathrm{N}$ and $\mathrm{C}$ concentrations in the stomach content implying the diet quality could be related to this ratio. $\mathrm{N}$ concentrations in the stomach per unit body mass were positively and significantly related to catch per unit effort of voles.

We suggest that sites with high $\mathrm{N}$ concentrations in stomach content and with higher NC-ratio imply better habitats that support higher population densities of voles.
\end{abstract}

Keywords: Vole body mass, nutritional status, catch per unit effort.

\section{INTRODUCTION}

Nitrogen $(\mathrm{N})$ is a fundamental element for organisms since it is a part of proteins and it is required for body growth and reproduction (Karasov and Martinez del Rio 2007). For herbivores, nitrogen balance is not as easily achieved as for carnivores since $\mathrm{N}$ may not be in a form that is readily transformed into body tissues. Likewise, the concentration of carbon (C) is usually higher in plants than in animals resulting in lower $\mathrm{N} / \mathrm{C}$ ratios that imply lower food quality of the former (Hodar and Palo 1997). Small mammalian herbivores such as the bank vole have high energy metabolism and turnover of essential nutrients. This suggests that small mammalian herbivores face a relative shortness of $\mathrm{N}$ and that this situation may be a potential cause for variations in population density between seasons and years (Hansson 1987, 1995, Batzli 1992, Hambäck et al. 2002, Wereszczynska et al. 2007). Protein requirement is a result of two components a) endogenous urinary excretion and b) fecal loss. The former is related to metabolic rate and the latter to the quantity of food processed. Thus the stomach content of nitrogen must balance these losses to satisfy maintenance requirements.

The role of critical nutrients is a controversial question, whether rodents living in a lower nutritional environment show smaller body size and lower population density than voles in more nutritious environments? It has been shown

*Address correspondence to this author at the Department of Natural Sciences, Engineering and Mathematics, Mid-Sweden University, SE-851 70 Sundsvall, Sweden; E-mail: thomas.palo@miun.se

Handling Editor: Marcelo Hernan Cassini that type of diet affects growth in bank vole, but also that adaptation to diet is important for regional differences in mass among populations of voles (Lidicker \& Ostfeld 1991, Hansson 1995, Norrdahl \& Korpimäki 2002). Body size and population size may be dependent on the intake of critical nutrients such as $\mathrm{N}$ and the ratio of $\mathrm{N}$ to $\mathrm{C}$ in the diet. Laboratory studies may be misleading since animals are usually on a high nutritional diet and may not reflect the situation in nature. In this study the variation in body mass, stomach concentrations of $\mathrm{N}$ and $\mathrm{C}$ in populations of free living bank voles in forest areas of northern Sweden are reported.

\section{MATERIALS AND METHODS}

Bank voles were collected at six sites along the coastal area of Västerbotten county in northern Sweden $\left(63^{\circ} 45^{\prime}\right.$ $63^{\circ} 20^{\prime}$ North latitude: $20^{\circ} 00^{\prime}-21^{\circ} 00^{\prime}$ East longitude (Ahlm et al., 1997)). The sites were paired at three localities separated by approximately a distance of $50 \mathrm{~km}$ from south to north (Fig. 1). Distance between paired sites was about $10 \mathrm{~km}$ in east-west direction. Habitats for voles at sampling sites consisted of managed and mixed conifer forests dominated by Scotch Pine (Pinus sylvestris) and Norway Spruce (Picea abies) of similar stand age (40-60 years), with considerable undergrowth of bilberry (Vaccinium myrtillus) and lingonberry ( $V$. vitis-idaéa), and were $\geq 5$ hectares size.

Bank voles were collected at each site in SeptemberOctober during the years 1995, 1996 and 1997. Animals were also trapped in May of 1998 reflecting the spring season. 


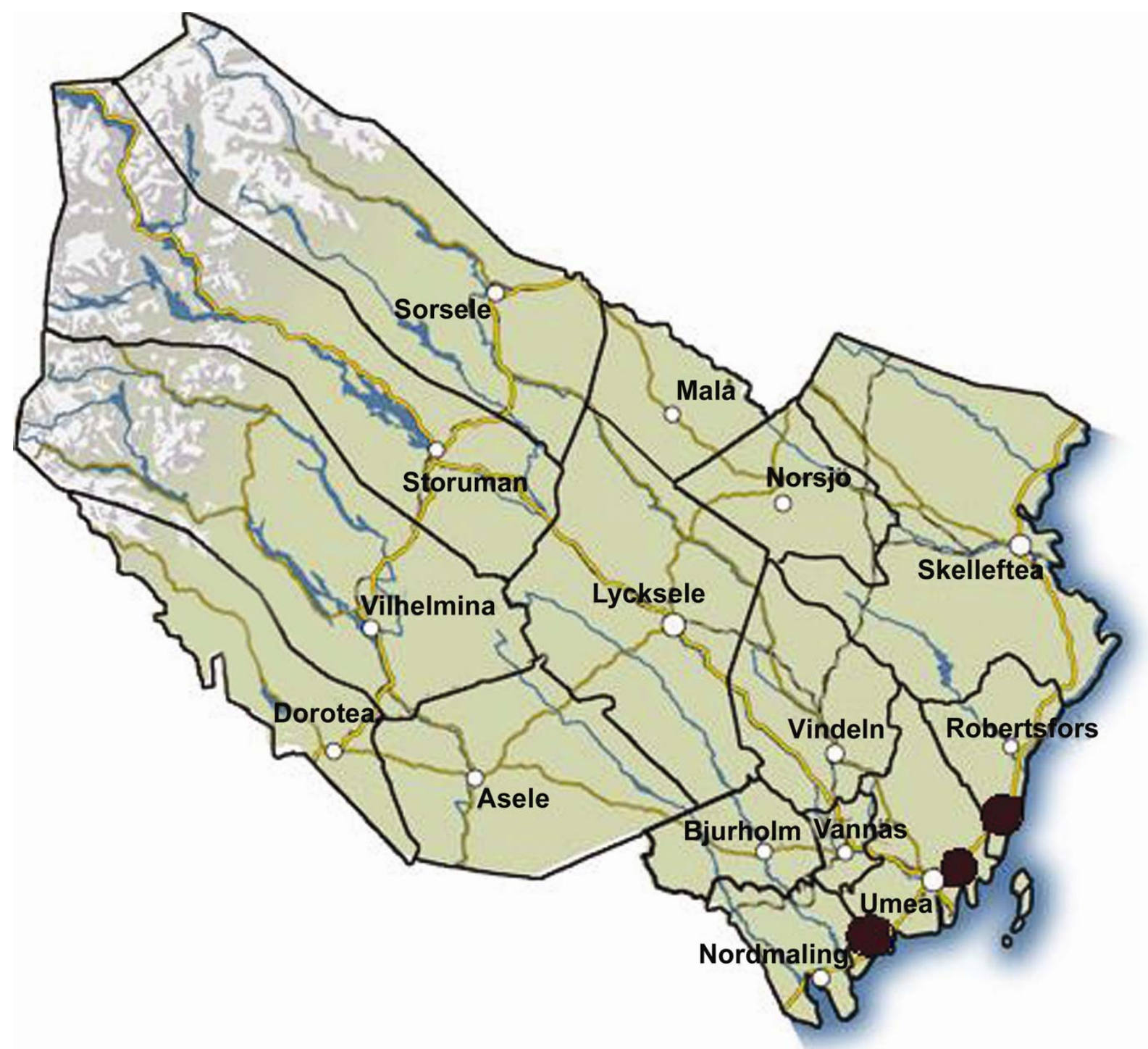

Fig. (1). Geographical locations of the study areas $(2)$. Each locality has two replicated sites separated by a distance of at least $10 \mathrm{~km}$.

For collection of animals, 180 snap-traps baited with dry apples were set during four nights constituting 720 trapnights per area of investigation. The animal is killed instantaneously and the bait is not consumed before death. The areas were sampled consecutively over three week periods and traps were checked early mornings once a day. The number of animals caught was transformed to an index related to number of traps and days, which is catch per unit effort (CPUE) (Hörnfeldt 1994).

Body mass (BM) was measured to nearest 0.1 gram and body length (BL) to $\pm 5 \mathrm{~mm}$. BL was not used as an separate variable but was included as body mass index (BMI) calculated as $B M I=\frac{B M}{(B L)^{2}}$ that is a measure of body status (Olsson et al. 2002).

Stomach contents from the animals caught in the autumn for the years $1995(\mathrm{~N}=38), 1997(\mathrm{~N}=82)$ and in the spring of $1998(\mathrm{~N}=81)$ were carefully rinsed out with sterile water and immediately dried at $50^{\circ} \mathrm{C}$ until 3 consecutive weights over 3 days did not differ more than 0.005 g. 1 gram of stomach content were analysed for $\mathrm{N}$ and $\mathrm{C}$ concentrations in a CHNelement analyser (Perkin-Elmer PE-2400, Norwalk, CT, USA).

Statistical analyses were performed in SYSTAT 12, version 12.02. The data of BM, BMI and NC-ratio were not normally distributed and therefore $\log$ transformed for statistical analysis (Lilliefors $\mathrm{p}<0.001$ ).

\section{RESULTS}

$\mathrm{BM}$ of the animals varied from $11.5 \mathrm{~g}$ to $29.2 \mathrm{~g}$ and varied significantly with site of collection and season (ANOVA, season $(\mathrm{F}=100.1, \mathrm{p}<0.0001$, site $(\mathrm{F}=3.09, \mathrm{p}<$ $0.011)$. Individuals in the spring were on the average $4.8 \mathrm{~g}$ heavier than individuals in the autumn populations (Student's t-test, $\mathrm{p}<0.0001)$. Sex of the animals did not add explanation to the variation in body mass (ANOVA, $\mathrm{F}=2.9$, $\mathrm{p}<0.092)$. 
Table 1. Basic Data on Sites, Coordinates of Locality, Year of Collection, Catch per Unit Effort (CPUE) and Mean Body Mass (BM)

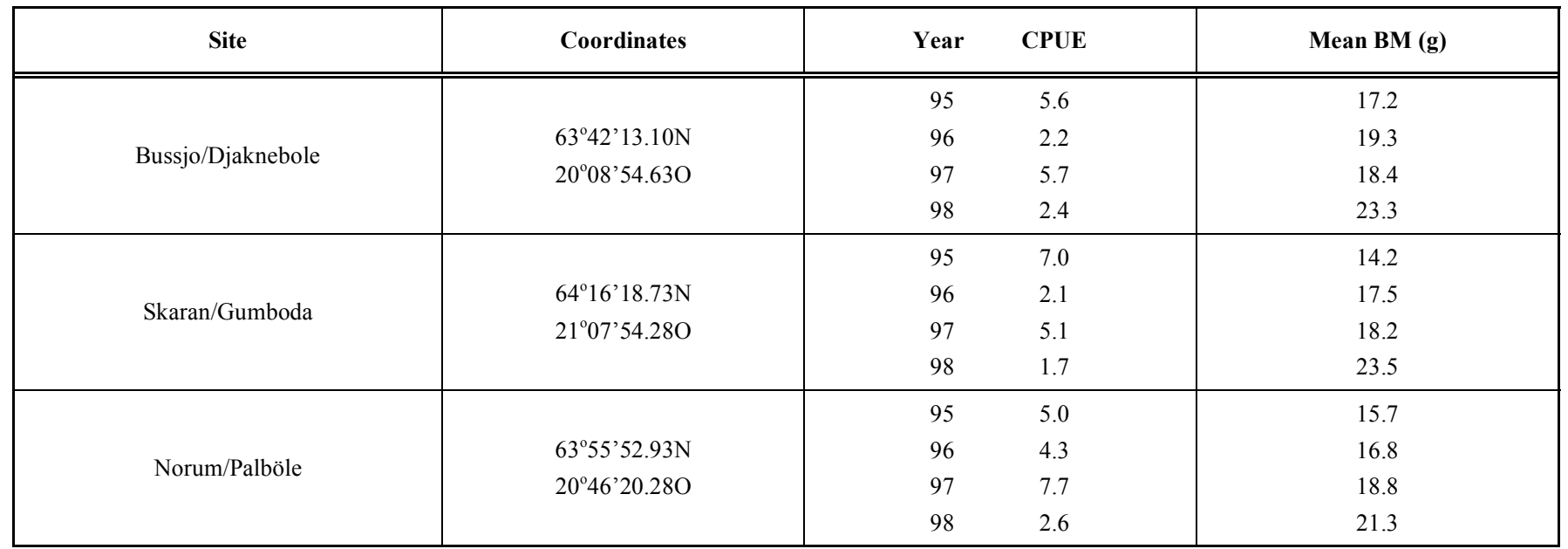

Basic data on the voles and the sites are found in Table $\mathbf{1 .}$ BMI was lower in the autumn population compared the spring populations and differed between sites (ANOVA, season $(F=11.6, p<0.001, d f=1)$, site $(F=4.39, p<0.001$, $\mathrm{df}=5)$ ). There is a significant season and site interaction, those sites with high BMI in the autumn also showed high BMI in the spring time (ANOVA, Fisher's $\mathrm{F}=5.685, \mathrm{df}=5$, $\mathrm{p}<0.0001)$. The sex of animals was not significant for variation in BMI (ANOVA, $\mathrm{F}=0.343, \mathrm{df}=1, \mathrm{p}<0.559$ ).

Nitrogen concentration in the stomach of voles did not vary with season but varied between sites of collection (ANOVA, Fisher's $\mathrm{F}=3.93, \mathrm{df}=5, \mathrm{p}<0.002$ ). The $\mathrm{N}$ concentration varied from $0.8 \mathrm{mg} \mathrm{g}^{-1}$ to $8.1 \mathrm{mg} \mathrm{g}^{-1}$ in the stomach content of individual voles. Despite that stomach $\mathrm{N}$ concen- tration varied between sites no differences related to variation in BM or BMI of animals were found. Carbon concentration in the stomach content covaried significantly with the variation in stomach $\mathrm{N}$ concentration. This relationship was apparent at two sites while no relationship was found at the other sites, partly due to few data points at these sites. NCratio varied between sites (ANOVA, $F=3.75, p<0.003$, $\mathrm{df}=5)$.

$\mathrm{N}$ concentration per unit BM only varied between seasons with higher $\mathrm{N} / \mathrm{BM}$ in spring time (ANOVA, $\mathrm{F}=3.98$, $\mathrm{p}<0.048)$.

A positive and linear relationship was observed between nitrogen concentration in the stomach content and CPUE, but the relationship was weak $(p<0.053)$. Since body mass

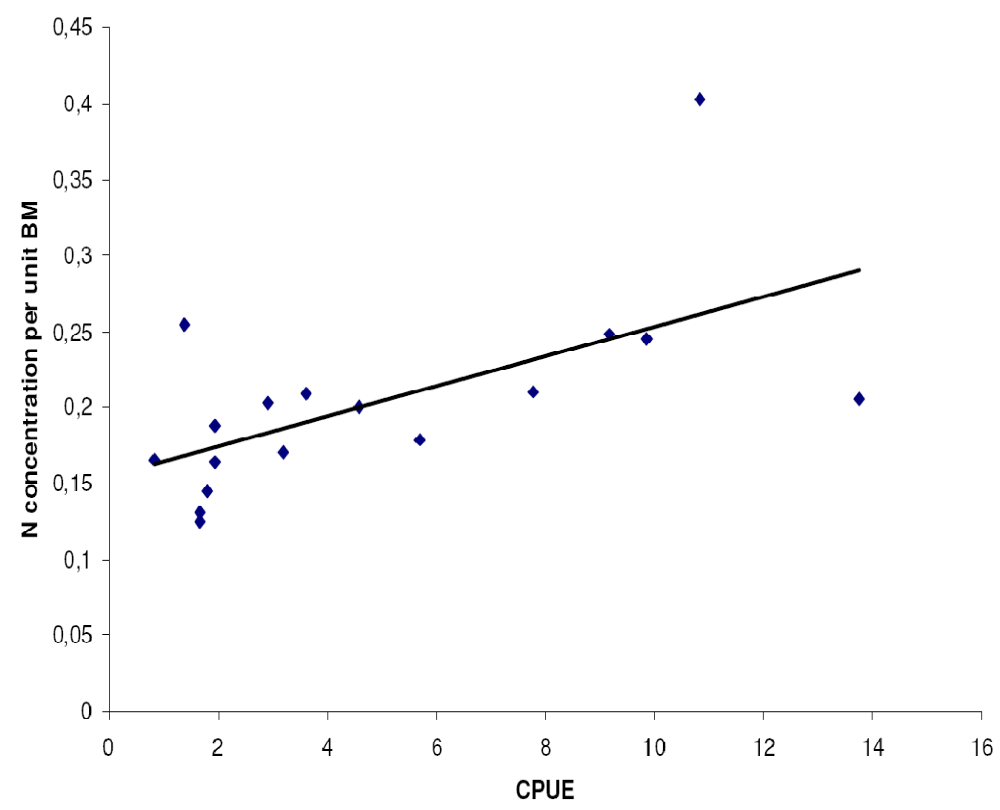

Fig. (2). Regression of nitrogen concentrations in stomach content of voles per unit BM in relation to CPUE. Data points are mean values per site and year. Equation $\mathrm{Y}=0.155+0.0098 \mathrm{X}, \mathrm{F}=8.57, \mathrm{p}=0.010, \mathrm{r}^{2}=0.363$. 
varied with sites we reduced a possible interaction effect on $\mathrm{N}$ concentrations by taking $\mathrm{BM}$ into account. The $\mathrm{N}$ concentration per unit BM strengthened the positive and linear relationship of $\mathrm{N}$ concentration to the CPUE of voles $\left(\mathrm{p}<0.015, \mathrm{r}^{2}=0.29\right)$, (Fig. 2).

\section{DISCUSSION}

The evaluation of habitat quality for herbivores is usually difficult since plant species and tissues vary in basic nutritional factors. There is currently a debate about how to incorporate nutrition into ecology and how to measure the currency that relates to animal fitness i.e. ecological stoichiometry and the geometrical framework (Raubenheimer et al. 2009). Here we utilised the stomach content of bank voles, i.e., food items chosen by the specimens themselves, to evaluate food/habitat quality. The diet of bank voles is varied and the most common food types are forb stems during spring time, dwarf-shrubs during autumn/winter, as well as some lichens and fungi (Hansson and Larsson, 1978). We found a considerable variation among individuals in the $\mathrm{N}$ concentration of the stomach content supporting a varied diet composed of different food types. In general, faecal and urinary excretions of $\mathrm{N}$ are positive functions of $\mathrm{N}$ intake (Bradshaw and Bradshaw 2001). The mean diet concentration $\left(3.4 \mathrm{mg} \mathrm{g}^{-1}\right)$ found here is below the nitrogen balance reported for prairie voles (Microtus ochrogaster), which is estimated to $5 \mathrm{mg} \mathrm{g}^{-1}$ and that is slightly larger species than the bank vole (Ditchkoff et al. 1998). The maintenance nitrogen requirement ( $\mathrm{mg} \mathrm{N}$ per day, MRN) scale to body mass according to $\mathrm{MRN}=411 \mathrm{M}^{0.863}$ where $\mathrm{M}$ is body mass in $\mathrm{kg}$ (Klaassen \& Nolet, 2008). From this the daily N needs for a vole range from $8.7 \mathrm{mg}$ to $19.5 \mathrm{mg} \mathrm{N}$ per day. Based on the range of $\mathrm{N}$ concentrations in the stomach and a digestibility of the food of $60 \%$ the daily food intake that satisfy the $\mathrm{N}$ need varies from $3.6 \mathrm{~g}$ to $8 \mathrm{~g}$. This is within the range of food intake reported for voles in captivity (Krol et al. 2004). The variation in concentrations of $\mathrm{N}$ was not reflected in animal performance such as BM or BMI. Thus we found no support for the hypothesis that low nutritional quality is associated with low body mass of voles. Large body size does not necessarily mean that these animals feed on high $\mathrm{N}$ diets. It is reported that variations in body mass are primarily associated with energy intake rather than nitrogen since the latter is linked to tissue maintenance in adults rather than growth (Robbins 1993). Experimental studies have shown that extra food and shelter are factors that positively affect survival and body mass of microtine rodents (Taitt et al. 1980, Taitt 1981, Taitt \& Krebs 1981). The present analysis of stomach nutritional factors is only one snapshot in time and may not be representative for long term nutritional status of the animals. On the other hand, the $\mathrm{N}$ concentration in the stomach was positively related to CPUE which imply that density of voles may dependent on diet quality. Our results suggest therefore that high diet quality may have stronger positive effects on survival or on reproduction rather than on factors determining body growth. Thus a mechanism operating trough the reproductive system may delay timing of reproduction for both males and females, possibly affect lactation or the oestrus of females (White 2008). These physiological effects by nutritional status need further studies. It seems from these results that better vole habitats based on the stomach $\mathrm{N}$ concentrations and higher NC-ratio support higher population densities of voles and these may also be environments that are attractive to voles due to higher food quality.

\section{ACKNOWLEDGEMENT}

Thanks to B. Aava, J. Green, A. Henningson, Å. Laurell, P. Nordin, and A. Verlemyr for assistance in the field. F. Dalerum and $\AA$. Nordström assisted with dissection of animals. Financial support for this study was given by CMF (no. 952114) and the EU contract (no. BMH4-CT97-2499).

\section{REFERENCES}

Ahlm, C, Alexeyev, O, Elgh, F, Aava, B, Wadell, G, Tärnvik, A, Palo, RT (1997) High prevalence of Hantavirus antibodies in bank voles (Clethrionomys glareolus) captured in vicinity of household afflicted with nephropathia epidemica. American Journal of Tropical Medicine and Hygiene, 56, 674-8.

Batzli, GO (1992) Dynamics of small mammal populations: a review. In: McCullough, DR, Barret, RH (Eds.). Wildlife 2001: Populations, Elsevier Science Publisher, 831-50.

Bradshaw, FJ, Bradshaw, SD (2001) Maintenance nitrogen requirement of an obligate nectarivore, the honey possum (Tarsipes rostratus). Journal of Comparative physiology $B, 171,59-67$.

Ditchkoff, SS, Boyd, CS, Welch Jr. ER, Raglin, JB, Lochmiller, RL (1998) Nitrogen Requirements of the Adult Prairie Vole (Microtus ochrogaster). The American Midland Naturalist, 387-92.

Hambäck, P, Grellmann, D, Hjältén, J (2002) Winter herbivory by voles during a population peak: the importance of plant quality. Ecography, 25, 74-80.

Hansson, L, Larsson, TB (1978) Vole diet on experimentally managed reforestation areas in northern Sweden. Holarctic Ecology, 1, 1626.

Hansson, L (1987) An interpretation of rodent dynamics as due to trophic interactions. Oikos, 50, 308-18.

Hansson, L (1995) Demographic effects of food quality on the bank vole Clethrionomys glareolus. EcoScience, 2, 41-47.

Hodar, J, Palo, RT (1997) Feeding by vertebrate herbivores in a chemically heterogeneous environment. EcoScience, 4, 304-10.

Hörnfeldt B (1994) Delayed density dependence as a determinant of vole cycles. Ecology, 75, 791-806.

Karasov, WH, Martinez del Rio, C (2007) Physiological Ecology. How Animals Process Energy, Nutrients and Toxins. Princeton University Press, USA.

Klaassen, M, Nolet, BA (2008) Stoichiometry of endothermy: shifting the quest from nitrogen to carbon. Ecology Letters 11, on line http://www.Blackwell-synergy.com/doi/full/10.1111/j.14610248.2008.01180.x.

Krol, E, Redman, P, Thomson, PJ, Williams, R, Mayer, C, Mercer, JG, Speakman, JR (2004) Effect by photoperiod on body mass, food intake and body composition in the field vole, Microtus agrestis. Journal of Experimental Biology, 208, 571-84.

Lidicker, WZ, Ostfeld, RS (1991) Extra-large body mass in California voles: causes and fitness consequences. Oikos, 61, 108-21.

Norrdahl, K, Korpimäki, E (2002) Changes in individual quality during a 3year population cycle of voles. Oecologia, 130, 239-49.

Olsson, G, White, N, Ahlm, C, Elgh, A, Verlemyr, A, Juto, P, Palo, RT (2002) Demographic factors associated with hantavirus infection in bank voles (Clethrionomys glareolus). Emerging Infectious Diseases, 8, 924-8.

Raubensheimer, D, Simpson, SJ, Mayntz, D (2009) Nutrition, ecology and nutritional ecology: towards and integrated framework. Functional Ecology 23, 4-16.

Robbins, CT (1993) Wildlife feeding and nutrition, $2^{\text {nd }}$ ed, Academic Press, San Diego.

Taitt, MJ, Krebs, CJ (1981) The effect of extra food on small rodent populations: II.Voles (Microtus townsendii). - Journal of Animal Ecology, 50, 125-37.

Taitt, MJ, Gipps, JHW, Krebs, CJ, Dundjerski, Z (1980) The effect of extra food and cover on declining populations of Microtus townsendii. Canadian Journal of Zoology, 59, 1593-9. 
Taitt, MJ (1981) The effect of extra food on small rodent populations: I. Deermice (Peromyscus maniculatus). Journal of Animal Ecology, $50,111-24$.

Wereszczynska, AM, Nowakowski, WK, Nowakowski, JK, Jedrzejewska, B (2007) Is food quality responsible for the cold-season decline in bank vole density? Laboratory experiment with herbs and acorn diets. Folia Zoologica, 56, 23-32.

White, TCR (2008) The role of food, weather and climate in limiting the abundance of animals. Biological Review, 83, 227-48.

(C) Palo and Olsson; Licensee Bentham Open.

This is an open access article licensed under the terms of the Creative Commons Attribution Non-Commercial License (http://creativecommons.org/licenses/by$\mathrm{nc} / 3.0 /$ ), which permits unrestricted, non-commercial use, distribution \& reproduction in any medium, provided the work is properly cited. 